専門医症例報告

\title{
臼歯部の咬合崩壊に対する補緅処置症例
}

\author{
小林 章二

\section{A Prosthodontic Treatment for Loss of Occlusal Support in Molar Regions Defect with Severe Resorption of Alveolar Bone}

Kobayashi Shoji

抄 録

症例の概要：患者は奥歯で物を咬めないことを訴え来院した， 臼歯部の咬合崩壊による咀嚼障害と診断し， プロビジョナルレストレーションを製作・装着後, 歯周治療, 抜歯, 根管治療を行いながらプロビジョナル レストレーションを調整した後, 固定性義歯により咬合回復を行った.

考察 :「1 の歯冠形態を保存したことにより，プロビジョナルレストレーションの製作および調整がスムーズ に行え，また最終補綴物に与える咬合状態の決定をも的確に行えたと考えられる.

結論：臼歯部の咬合が崩壊した症例で，抜歯が必要である歯もプロビジョナルレストレーションの調整期間 中に一時的に残し治療を進めた結果，治療期間中に患者に与える不具合を最小限にとどめ，スムーズに咬 合回復を行うことができた.

和文キーワード

咬合崩壊，プロビジョナルレストレーション

\section{ABSTRACT}

Patient: The patient's chief complaint was difficulty of mastication in molar regions. The diagnosis was masticatory dysfunction caused by loss of occlusal contacts. Initially provisional restorations were fabricated, then disharmonious contours were corrected during the following treatments including endodontic and periodontic treatments and tooth extraction. Final restorations were made with fixed partial dentures.

Discussion: Preservation of the left incisor of mandible enabled recontouring the provisional restoration and consequently, determining a definitive occlusal scheme for the final restoration.

Conclusion: For a patient with collapse of posterior occlusal contacts, hopeless teeth which should be extracted were used as temporary abutment for the provisional restoration. This treatment plan minimized trouble for the patient during treatment, resulting in successful final occlusal reconstruction.

\section{Key words}

loss of occlusal support, provisional restorations

東関東支部（(株）日立製作所水戸総合病院医務局第二歯科）

Higashi-Kanto Branch (Department of Dentistry II, Mito General Hospital., Hitachi, Ltd.)

受付 : 2007 年 7 月 1 日/受理 $: 2008$ 年 1 月 20 日

Received on July 1, 2007/Accepted on January 20, 2008 


\section{I. 緒言}

咬合が崩壊した症例では, 残存歯を保存できるか 否かの見極めと，プロビジョナルレストレーションを 用いた調整が，咬合回復の成功のために不可欠であ る。今回，本来ならば，抜歯が必要である歯もプロビ ジョナルレストレーションの調整期間中に一時的に 残し，患者に与える不具合を未然に防ぐ治療計画に 基づき治療を進めた症例について報告する。

\section{II. 症例の概要}

患者： 51 歳, 男性

初診：2000 年 10 月 12 日

主訴：奥歯で物を咬めない

既往歴：特になし

現病歴：1991 年の頃から, $532 \mid 2, \overline{76432 \mid 4567}$ の歯冠修復物が徐々に外れてしまったが，そのまま 放置していた.

現症：欠損歯は 45,5 万のみだが， $532 \mid 2 ， \overline{76432}$ $\overline{4567}$ の歯冠修復物の脱離あるいはう蝕により歯冠 が崩壊しており，臼歯部の咬合支持は喪失していた。 なお，歯冠が残っている歯の中で，前歯の $1 \mid 13 ， 1$ $\overline{123}$ の歯軸には異常は認められなかった(図 1, 2).

診断:

1）臼歯部の咬合崩壊による咀嚼障害

2) 4 5, 5 欠損

3） $61 \mid 6 ， \overline{6431456}$ 慢性根尖性歯周炎

4) $3|37,1| 23$ 不可逆性歯髄炎

5） $41 \mid 16$ 歯冠修復物不適合

6) $\underline{52 \mid 2}, \overline{72 \mid 47} \mathrm{C} 4$

7) 7$\rfloor \mathrm{C} 2$

8）全顎的に中程度の辺縁性歯周炎 治療計画 :

1）歯周初期治療を行った後，プロビジョナルレ ストレーションを製作し, 暫間的な咬合回復を行う.

2) 保存できると判断した歯の歯内療法を順次行い, メタルコア装着後プロビジョナルレストレーションを 調整してゆく.

3）歯内療法, メタルコア装着の進渉状況に応じて 保存不可能な歯の抜歯を行う.

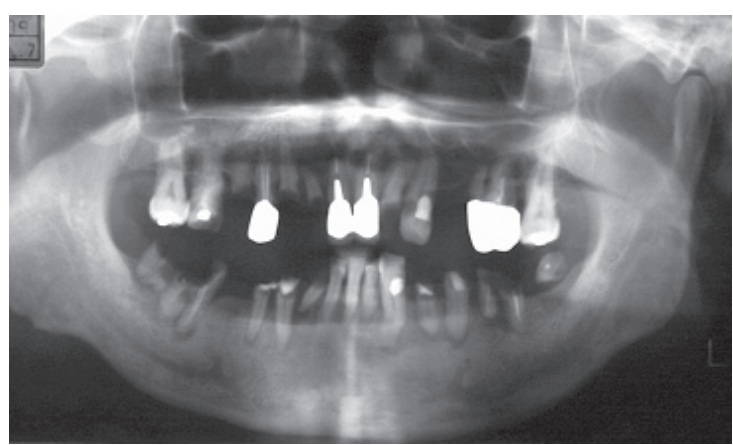

図 1 Panoramic X-ray at the first examination 初診時のオルソパントモグラフィー
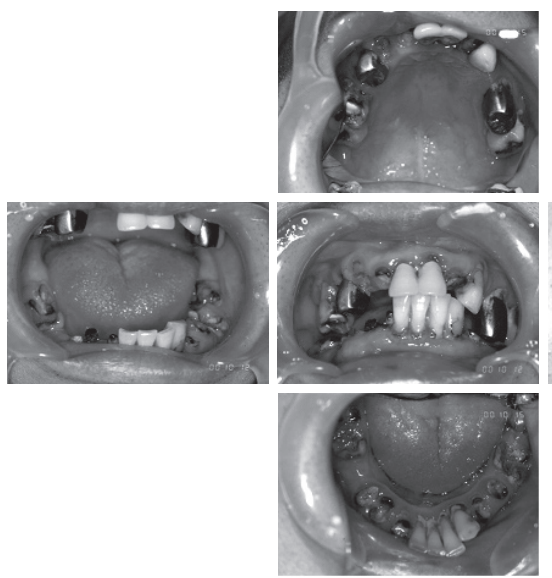

図 2 Intraoral views at the first examination 初診時の口腔内写真

4）プロビジョナルレストレーションにおいて，審 美性および機能の問題が解消された時点で最終補綴 物の製作に移行する.

\section{III. 治療内容と経過}

\section{1. 治療内容}

2000 年 10 月, 初診時の診察において $\underline{1 \mid 13}, \overline{1 \mid 123}$ のフレアーアウトはないと判断したので，中心位に誘 導して $1 \mid 13, \overline{11} 123$ が接触する咬合高径を記録し, 既存のアンテリアガイダンスを半調節性咬合器にトラ ンスファーを行い，プロビジョナルレストレーション を製作した，次に, 435 の歯内療法を行い, メタルコ アを装着し(6)5(4)(3), (2)(3)(4)(5)のプロビジョナルレ ストレーションを装着した. また $41 \mid 16$ の不適合冠を 除去し, (6) (5) (4) (3) (2) (1)|(1) (2) (3) 45 (6)のプロビジョ 


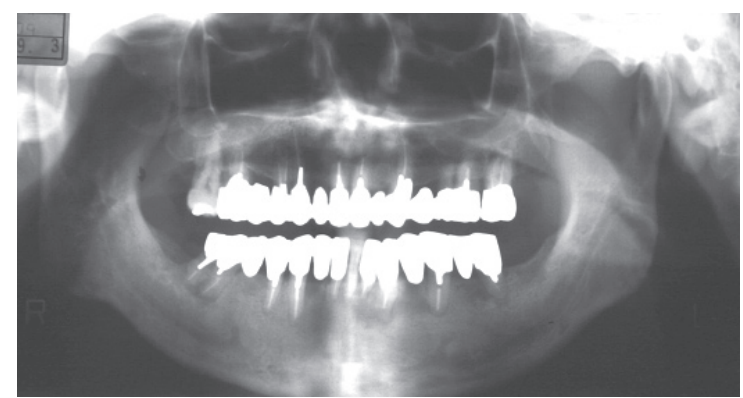

図 3 Panoramic X-ray after prosthodontic treatment 最終補綴装置装着後のオルソパントモグラフィー

ナルレストレーションを装着した。ささらに, $\mid 3, \overline{6 \mid 23}$ の歯内療法を行い, メタルコアを装着した。 6 は髄 床底が薄く, 単冠による歯冠修復は不可能と判断し たので，セパレーションを行った。

上顎のプロビジョナルレストレーションが安定して いると判断したので， $52 \mid 2$ を抜歯した， 3 にメタルコ アを装着し, (6) 5 (4) (3)2 (1)|(1) 2 (3) 45 (6)のプロビジョ ナルレストレーションを調整した. 次に, $61 \mid 6$ の歯 内療法を行い, メタルコアを装着した。

これまでの上顎のプロビジョナルレストレーショ ンにおいて，審美性および機能の問題が解消され， 経過は良好と判断したので，2002 年 1 月より，上顎 の最終補緅物の製作を開始した。最終補綴物は, (6) 5 (4), (3) 2 (1), および (1) 2 (3) 45 (6)のスリーピー スの固定性ブリッジとすることとした。 2002 年 2 月 にブリッジを仮着し，経過観察をしたところ，問題が ないと判断したので，ブリッジを合着した。 上顎の治 療を先に終了するため, 17 の歯内療法を行い, 歯冠 修復を行った。

次に, 下顎の最終補綴物を製作するために, 2002 年 5 月 7 の抜歯を行い, $\sqrt{6}$ の歯内療法を行ったが, $\lceil$ の近心根は保存不可能と判断し, ヘミセクション を行い，近心根を抜去した。 6 遠心根にメタルコアを 装着して, (2)(3) (4)(5)6 (6) のプロビジョナルレスト レーションを調整し, $\sqrt{4}$ の抜歯を行った。創傷の治 癒を待ち, (2) (3) 4(5)6 6) の固定性ブリッジの製作を 開始し, 平成 2002 年 7 月, 仮着とした.

2002 年 7 月 72 の抜歯を行い，11の支台歯形成を 行い, (6) (6) 5(4)(3)2(1)のプロビジョナルレストレー ションを調整した。 11 は支台歯形成の影響と考えら
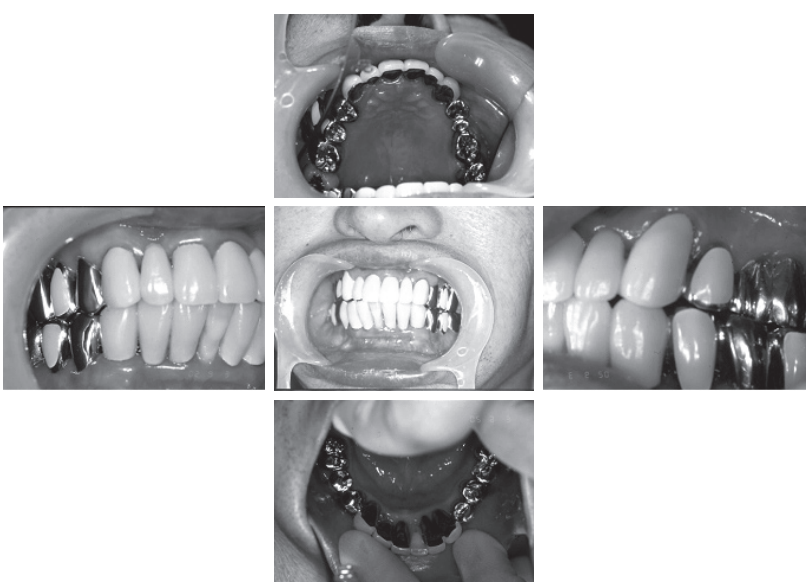

図 4 Intraoral views after prosthodontic treatment 最終補緅装置装着後の口腔内写真

れる自発痛の症状が発生してしまったため, 1を抜 髄し，レジンコアで支台歯を調整した。

2002 年 8 月, (6) (6) 5 (4) (3) 2 (1) の固定性ブリッジの 製作を開始し, 2002 年 8 月ブリッジを仮着し, 経過 観察をしたところ，問題がないと判断したので， (6) (6) 5 (4)(3) 21 (1), (2) (3)(4)(5)6 (6)のブリッジを同時に 合着した。

2002 年 9 月, 歯周組織精密検査を行い, スケーリ ングを行った．この時，7怩にう蝕が認められたため, う蝕処置を行い，再度口腔清掃指導を行い，問題が ないと判断したので治療を終了し，定期検診とした (図 3,4).

\section{2. 経過}

治療終了後は, 定期的な検診を行い, 術後管理を 半年ごとに行い現在に至っている. 現在 4 年 5 力月 が経過しているが, 補緅物の動摇は認められず, また, 各歯の歯周ポケットの梁さは, 治療終了時の数值と ほとんど変化は認められない。 また，咬合状態も良好 に保たれており，患者の満足が得られている。

\section{IV. 考 察}

初診のレントゲン像や口腔内所見から, 即座に抜 歯しなければならないと判断された歯をすぐに抜くの ではなく, 保存できる歯の歯内療法, メタルコア装着 の進渉状況に応じて, 抜歯の時期を治療途中に適切 
に組み込んだことにより，治療期間中のプロビジョナ ルレストレーションを安定して装着することができ た.つまりプロビジョナルレストレーションの脱離が ほとんど生じず患者の負担を軽減することができた. また，「の補緅処置を行わずに済んだことにより，こ の『1 がプロビジョナルレストレーションの装着におい て, 口腔内に扔ける咬合平面や咬合高径想定の一つ の指標となり, プロビジョナルレストレーションの調 整をスムーズにし, さらに最終的な咬合状態の模索 を的確に行え, 最終補綴物の形態の決定に寄与した と考えられる。このような治療計画を立てたことによ り, 治療中の患者の負担を軽減するとともに, 最終 補緅物の形態上の不確定要素を最小限にとどめるこ とができたと考えられる。

\section{V. 結論}

臼歯部の咬合が崩壊した症例で, 残存歯を保存で きるか否かを適切に見極め, 抜歯が必要である歯も プロビジョナルレストレーションの調整期間中に一 時的に残し治療を進め, 咬合回復を行うことができ た、その結果, 主訴を改善することができ, 長期にわ たる良好な結果を得られることができた。

著者連絡先 : 小林 章二

テ 312-8506 ひたちなか市市毛 1070

TEL : 029-275-4231

FAX : 029-275-4656

E-mail : shoji.kobayashi.kf@hitachi.com 